DOI 10.18551/rjoas.2019-09.14

\title{
A RESOURCES-BASED VIEW OF A MEDICAL DEVICES COMPANY IN INDONESIA
}

\author{
Fazrullah Maulana*, Jahroh Siti, Kirbrandoko \\ School of Business, IPB University, Indonesia \\ *E-mail: maulana.fazrullah@gmail.com
}

\begin{abstract}
The purpose of this study was to analyze the core competencies of a medical devices company in Indonesia. Based on the resource-based view, distinct core competencies derive the company's competitive advantage compared to its competitors. The company's core competency itself is a series of competencies owned by the company that is formed from the company's ability to manage both tangible and intangible resources. The study was conducted for two months with a descriptive qualitative research method. In-depth interview techniques were conducted face-to-face with questionnaire guidelines. External and internal respondents in this study were selected based on specific criteria (purposive sampling). VRIO Analysis is used in this study to formulate the core competencies of the company.
\end{abstract}

\section{KEY WORDS}

Competitive advantage, core competencies, VRIO analysis, public service.

Indonesian Medical Devices and Laboratory Association (Gakeslab) is optimistic that the domestic medical equipment industry will continue to grow. The current market value of medical devices can reach twenty trillion (IDR) in a year (Simbolon, 2018). Also, the growth of the medical device market in Indonesia is predicted to grow up to $13 \%$ per year (Pharmaboardroom, 2018). Surely this is a desirable market. It showed in 2018 that there are 411 medical equipment companies (Putera, 2018) that compete in this market, and of course, this number will continue to grow from time to time.

PT Kalbe Farma Tbk (Kalbe) is one of the largest pharmaceutical company in Indonesia. The company founded PT Enseval Medika Prima (EMP) as a step to focus its business activities in the field of marketing and trade in medical devices. Besides offering distribution services, EMP is also a provider of marketing services for medical devices for business partners. EMP is determined to win the market. Therefore, EMP needs to implement the right strategy to be able to face competition, and this strategy can help EMP continue to compete in the future. EMP must be more aggressive in competing in the market today and in the future and gaining even greater market share.

Based on the previous explanation, this research needs to be done to see how EMP can compete in the medical device business through a resource-based view. The business competition that continues to increase in the medical equipment business requires EMP to continue to develop its business and implement the right strategies to be able to compete with its competitors so that it is expected to increase market share and grow their business. This issue is further strengthened by the size and attractive growth of the market. To be able to compete in the market for medical devices, a competitive advantage strategy is needed by creating valuable competencies for its customers and having advantages over competitors, as well as being rare and maintained or difficult to imitate, which is then referred to as core competencies. A resource-based view can help identify which resources and capabilities are EMP's core competencies that are used as sustainable competitive advantages.

\section{LITERATURE REVIEW}

Associating between business competition and the company's strategy to excel compared to its competitors, and then there is one concept in strategic management in the form of competitive advantage. A company is declared to have a competitive advantage if it can create more economic value from its competitors in the market. The economic value 
created by a company in order to provide services and products is the difference between the benefits felt and obtained by the buyer for goods and costs incurred to the company (Peteraf and Barney, 2003). According to Porter (1985), competitive advantage is the ability to produce returns on investment consistently above the industry average. Therefore, this means that a company can achieve a competitive advantage if the company implements a value creation strategy that is not simultaneously implemented by current competitors or potential competitors. Barney (1991) shows that strategic resources generate a sustainable competitive advantage. Which he considers being internally controlled and allows companies to formulate and implement strategies that broaden their efficiency and effectiveness.

Resource-based view or commonly known as RBV is an approach taken to achieve competitive advantage from an organization initiated by B. Wernerfelt, Prahalad and Hamel, J. Barney, and others between 1980 and 1990s. Proponents of this view believe that an organization must look into the company itself to find sources of competitive advantage rather than focusing on the competitive environment. RBV for competitive advantage shows that internal resources are more critical for a company than external factors in achieving and maintaining a competitive advantage. The RBV's view emphasizes that organizational performance will primarily be determined by internal resources that can be grouped into three categories that cover all: physical resources, human resources, and organizational resources. Physical resources include factories and equipment, location, technology, raw materials, machinery. Human resources include all employees, training, experience, intelligence, knowledge, skills, abilities; and organizational resources including company structures, planning processes, information systems, patents, trademarks, copyrights, databases, and so on. The RBV theory asserts that resources are the real ones that help companies take advantage of opportunities and neutralize threats (David, 2011)

According to Barney and William (2015), resources in the RBV are defined as tangible and intangible resources that are controlled by a company that can be used to understand and implement its strategy. Hitt et al. (2017) state that tangible resources are resources that can be observed and measured. Production equipment, manufacturing facilities, distribution centres, and formal reporting structures are examples of tangible resources. Intangible resources are resources that are deeply rooted in the history of the company, accumulated over time, and are relatively difficult for competitors to analyze and replicate. Because they are embedded in a unique pattern of routines, intangible resources are difficult for competitors to analyze and imitate. Knowledge, trust between managers and employees, managerial abilities, organizational routines (the unique way people work together), scientific capabilities, innovation capacity, brand names, company reputation from goods or services, and organizational culture are intangible resources. Capability is the ability of a company to exploit these resources. Capability consists of business processes and routine things that are done in managing interactions between resources that convert the input into the output. For example, marketing capabilities are interactions between marketing teams, distribution channels, and sales teams. Capability is functionally based and attached to specific functions. Thus, there are marketing capabilities, manufacturing capabilities, human resource management capabilities. When these capabilities continue to change and are configured to make them more adaptive to uncertain environments, they are referred to as dynamic capabilities (Schreyogg and Kliesch-Eberl, 2007).

Based on the resource-based view, the different core competencies derive the company's competitive advantage compared to its competitors. The company's core competency itself is a series of competencies owned by the company that is formed from the company's ability to manage both tangible and intangible resources. Core competency is a collection of competencies that cross divisional boundaries, are widespread within the corporation, and are something that the company can do in an excellent way (Wheelen and Hunger, 2012).

Barney, through the VRIO framework, proposes four questions to analyze and evaluate company competencies. The questions are:

- Value: Do a firm's resources and capabilities enable the firm to respond to environmental threats or opportunities? 
- Rareness: Is a resource currently controlled by only a small number of competing firms?

- Imitability: Do firms without a resource face a cost disadvantage in obtaining or developing it?

- Organization: Are a firm's other policies and procedures organized to support the exploitation of its valuable, rare, and costly to imitate resources?

Resources and capabilities that meet the above questions which represent four criteria are valuable, rare (rare/unique), costly to imitate (expensive to imitate), and organization (organized) referred to as core competencies.

Table 1 - VRIO analysis: is a resource or capability

\begin{tabular}{|c|c|c|c|l|l|}
\hline Valuable? & Rare? & $\begin{array}{c}\text { Costly to } \\
\text { imitate? }\end{array}$ & $\begin{array}{c}\text { Exploited by the } \\
\text { organization? }\end{array}$ & $\begin{array}{c}\text { Competitive } \\
\text { implication }\end{array}$ & \multicolumn{1}{|c|}{ Strength or Weakness } \\
\hline No & - & - & No & $\begin{array}{l}\text { Competitive } \\
\text { disadvantage }\end{array}$ & Weakness \\
\hline Yes & No & - & No & Competitive parity & Strength \\
\hline Yes & Yes & No & No & $\begin{array}{l}\text { Temporary competitive } \\
\text { advantage }\end{array}$ & $\begin{array}{l}\text { Strength and distinctive } \\
\text { competence }\end{array}$ \\
\hline Yes & Yes & Yes & Yes & $\begin{array}{l}\text { Sustained competitive } \\
\text { advantage }\end{array}$ & $\begin{array}{l}\text { Strength and distinctive } \\
\text { sustainable competence }\end{array}$ \\
\hline
\end{tabular}

According to Hamel and Prahalad (1990), the company is like a tree that grows from its roots. The core product is maintained by competence and gives rise to a business unit, whose fruit is the final product. Therefore, companies need to know what their current competencies are and continue to improve their competencies so they can continue to grow and develop. If they want to expand their business, they also need to know what competencies are needed so that their new business can succeed in the future.

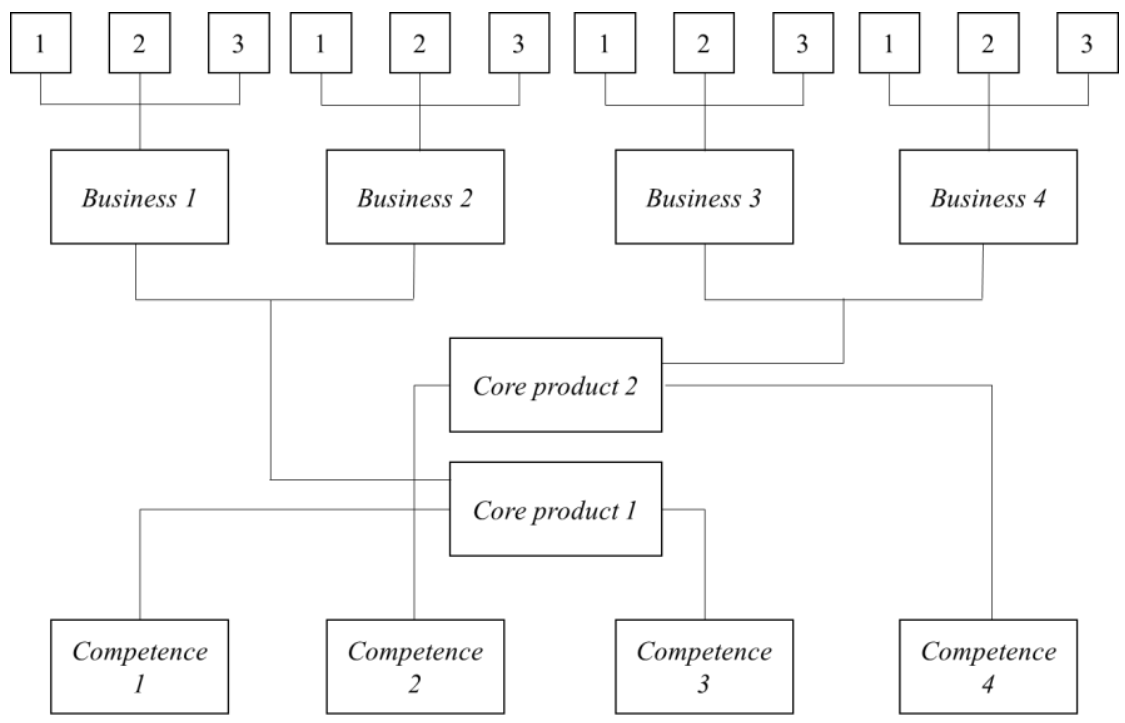

Figure 1 - Competencies: The roots of competitiveness

\section{METHODS OF RESEARCH}

This research was conducted in May 2019 until June 2019. The research method used was descriptive qualitative research method. Geertz (1973) described the power of qualitative research as getting a "thick description" or better understanding the context of an issue. There are several reasons why this research uses qualitative design. First, the qualitative approach focuses on the importance of the individual in it. Second, the qualitative approach is very suitable in exploratory studies where little knowledge is there. Besides, a qualitative approach can provide a quick understanding to help decisions when time is a 
problem (MacDonald, 2007). The qualitative approach also provides a detailed description of the life experiences of study participants. The descriptive research method is aimed at describing the characteristics of an object of people, groups, organizations, and the environment. One simplified approach of this research is the survey approach (Sumarwan et al., 2018). Descriptive research methods are used to obtain an overview of information, explanations, and conditions relating to the object of research in factually accurate and systematic. This study uses respondents consisting of directors, managements (internal respondents), and business partners (external respondents) from EMP (a medical devices company in Indonesia). The list of respondents is presented as follows:

Table 2 - List of respondents

\begin{tabular}{|l|l|}
\hline Code & Area of function \\
\hline Respondent 1 & Director 1 \\
\hline Respondent 2 & Director 2 \\
\hline Respondent 3 & Head of Marketing Department 1 \\
\hline Respondent 4 & Head of Marketing Department 2 \\
\hline Respondent 5 & Head of Marketing Department 3 \\
\hline Respondent 6 & Head of Marketing Department 4 \\
\hline Respondent 7 & Head of Marketing Department 5 \\
\hline Respondent 8 & Head of Marketing Department 6 \\
\hline Respondent 9 & Head of Business Support Department 1 \\
\hline Respondent 10 & Head of Business Support Department 2 \\
\hline Respondent 11 & Head of Business Support Department 3 \\
\hline Respondent 12 & Head of Business Support Department 4 \\
\hline Respondent 13 & Head of Business Support Department 5 \\
\hline Respondent 14 & Head of Business Support Department 6 \\
\hline Respondent 15 & President Director of Business Partner ${ }^{\mathrm{a}} 1$ \\
\hline Respondent 16 & President Director of Business Partner ${ }^{\mathrm{a}} 2$ \\
\hline
\end{tabular}

${ }^{a}$ Business Partner is a manufacturer or owner of a product or brand both from domestic and abroad who markets its products or brands through PT Enseval Medika Prima as their marketing agent in Indonesia.

Table 3 - Research steps

\begin{tabular}{|c|l|}
\hline Step & \multicolumn{1}{c|}{ Description } \\
\hline $\begin{array}{c}\text { Business Partner } \\
\text { in-depth interview }\end{array}$ & $\begin{array}{l}\text { Identify resources and capabilities that owned by EMP - exploring business } \\
\text { partner considerations in selecting EMP as their marketing and distribution agent. }\end{array}$ \\
\hline $\begin{array}{c}\text { Management } \\
\text { in-depth interview }\end{array}$ & Deliver the results and conclusions of the business partner interview. \\
\hline $\begin{array}{c}\text { Management } \\
\text { in-depth interview }\end{array}$ & $\begin{array}{l}\text { Identify the current resources and capabilities of EMP and assess them with a Likert } \\
\text { scale (1) very low, (2) low, (3) medium, (4) high and (5) very high. } \\
\text { VRIO analysis. }\end{array}$ \\
\hline $\begin{array}{c}\text { Director } \\
\text { in-depth interview }\end{array}$ & $\begin{array}{l}\text { Deliver the results and conclusions of the business partner interview and the } \\
\text { Identify the current resources and capabilities of EMP and assess them with a Likert } \\
\text { scale (1) very low, (2) low, (3) medium, (4) high and (5) very high. } \\
\text { VRIO analysis. }\end{array}$ \\
\hline
\end{tabular}

Data collection technique is using purposive sampling. This technique is done by selecting respondents based on specific criteria (Sumarwan et al., 2018). This study uses primary data collection techniques carried out by survey techniques, namely in-depth interviews with questionnaire guidelines. Also, secondary data collection was carried out to support research by collecting literature studies from textbooks, journals, results of previous research and company-owned documentation as well as publication data from related companies and institutions as well as internet search results relevant to research.

In this research, the resources and capabilities chosen to be analyzed with VRIO analysis are those who have high levels of competence (4) and very high (5) to represent the resources and capabilities of the company because it shows an essential contribution to the company. The higher the number for one competency, the more critical it is for EMP. The technique for knowing core competencies is by using VRIO analysis (Valuable, Rare, Inimitability, Organizational). This method starts with placing tangible, intangible resources, 
and capabilities as inputs. Then select whether the resources and capabilities possessed provide value for customers (valuable), are rarely owned by other companies (rare), are not easily imitated (inimitability), and companies organize these competencies (organizational) (Barney and William, 2015). After obtaining the conclusions of core competencies from the two perceptions of management and directors, competency trees can be formed to describe the structure and flow of competencies that form EMP competitive advantages.

\section{RESULTS AND DISCUSSION}

EMP is a subsidiary of Kalbe, which was founded in 2007 as a Kalbe's step to focus on business activities in the field of marketing and trading of medical devices. The company is engaged in the marketing and trading of medical devices that not only offer their brands or products but also become providers of marketing services for medical devices for business partners. There are two directorates in the organization, namely marketing, and business support. The marketing directorate has seven departments are:

- Institutional sales management (ISM), which functions as a department whose task is to market the company's products to government institutions and establish good relations with these institutions;

- Hospital furniture department that markets hospital furniture such as hospital bed;

- Hospital laboratory department 1, which markets hospital laboratory product lines;

- Hospital laboratory department 2, which markets hospital and industrial laboratory product lines;

- Hospital consumables department that market medical consumables product lines such as syringes, masks, gloves, etc;

- Hospital instrument department that market technology-based medical device product lines in hospitals such as ventilator machines, incubators, electric surgical machines, ultrasound, and CT scans;

- Personal health department that markets personal medical devices product lines directly to consumers.

The business support directorate has nine departments, namely finance and accounting, marketing finance, technology and information, business development, human and general resources, after-sales services, supply chain, regulatory affair and scientific, and legal. All of these departments function to support the marketing department, especially those related to the company's internal business processes.

The preliminary step, business partner in-depth interview, before identifying the resources and capabilities of EMP is done to provide an initial description for management and directors about the perceptions of external parties namely business partners about the resources and capabilities possessed by XZY. The result is undoubtedly expected to facilitate management and directors in identifying the resources and capabilities they have. The chosen business partner is loyal partner and has a significant business contribution to the company. The results of the business partner in-depth interview showed that the tangible resources possessed by EMP were distribution facilities with Kalbe support reaching throughout Indonesia, the number of sales forces, financial strength with Kalbe support and business process systems. Also, the business partners assessed that the intangible resources possessed by EMP were professionalism, reputation in the health sector with Kalbe support, customer relations, regulatory compliance, consistency. As for capabilities, the business partners stated that EMP has continuous improvement, continuous learning, managerial capabilities, marketing capabilities, change management, and information system management.

The conclusion of the first in-depth interview was delivered to management before the in-depth interview process. It is carried out to provide an overview and as a confirmation. The results of management in-depth interviews indicate that EMP's core competencies from management perceptions are dominated by tangible resources. Distribution facilities were the most mentioned by the respondents. The distribution facilities mean distribution 
infrastructure spread across almost all of Indonesia, which is inseparable from the support of its parent company, Kalbe, which is engaged in distribution. Its facilities make the distribution coverage of products from EMP extensive. This core competency is undoubtedly a distinct advantage because Indonesia is an archipelagic country, and it is not easy to distribute products throughout Indonesia. This distribution facility was mentioned as a core competency by respondent 3 , respondent 4 , respondent 5 , respondent 6 , respondent 7 , respondent 8 , respondent 9 , respondent 10 , and respondent 13 . The number of sales forces was mentioned as a core competency by respondent 3 , respondent 5 , respondents 6 , respondents 7 , respondents 9 , and respondents 13 . The number of sales forces means, for example, as mentioned by respondent 6 , complete sales forces in the organization, spread throughout Indonesia. Respondent 7 mentioned that the number of sales forces is a lot and spread throughout Indonesia, and respondent 9 said that the number of sales forces spread throughout the territory of Indonesia. The next core competency is financial resources. This core competency was mentioned by respondents 5 , respondents 6 , respondents 7 , respondents 8 , respondents 9 , and respondents 13 . They mentioned that EMP's substantial financial resources were inseparable from the support of the parent company. The core competency of the last tangible resource is the product portfolio. This core competency was mentioned by respondent 7 , namely the technological exclusivity of their products, and there is a one-stop solution if collaborated with Kalbe.

Table 4 - VRIO analysis from management perceptions

\begin{tabular}{|c|c|c|c|c|c|c|}
\hline Category & Resources or Capabilities & V? & $\mathrm{R} ?$ & I? & $\mathrm{O} ?$ & Competitive implication \\
\hline Tangible & Business process system & $\sqrt{ }$ & $\sqrt{ }$ & $x$ & & Temporary competitive advantage \\
\hline Tangible & Distribution facilities & $\sqrt{ }$ & $\sqrt{ }$ & $\sqrt{ }$ & $\sqrt{ }$ & Sustainable competitive advantage \\
\hline Tangible & Number of sales forces & $\sqrt{ }$ & $\sqrt{ }$ & $\sqrt{ }$ & $\sqrt{ }$ & Sustainable competitive advantage \\
\hline Tangible & Product portfolio & $\sqrt{ }$ & $\sqrt{ }$ & $\sqrt{ }$ & $\sqrt{ }$ & Sustainable competitive advantage \\
\hline Tangible & Financial resources & $\sqrt{ }$ & $\sqrt{ }$ & $\sqrt{ }$ & $\sqrt{ }$ & Sustainable competitive advantage \\
\hline Tangible & Technology and information & $\sqrt{ }$ & $\sqrt{ }$ & $x$ & & Temporary competitive advantage \\
\hline Tangible & Operational cooperation investment & $\sqrt{ }$ & $\sqrt{ }$ & $x$ & & Temporary competitive advantage \\
\hline Intangible & Business ownership & $\sqrt{1}$ & $\sqrt{1}$ & $\sqrt{ }$ & $x$ & Unused competitive advantage \\
\hline Intangible & Customer relationship & $\sqrt{ }$ & $\sqrt{ }$ & $\sqrt{ }$ & $\sqrt{ }$ & Sustainable competitive advantage \\
\hline Intangible & Business partner relationship & $\sqrt{ }$ & $\sqrt{ }$ & $x$ & & Temporary competitive advantage \\
\hline Intangible & Commitment & $\sqrt{ }$ & $\sqrt{ }$ & $\sqrt{ }$ & $\sqrt{ }$ & Sustainable competitive advantage \\
\hline Intangible & Coordination and collaboration & $\sqrt{ }$ & $\sqrt{ }$ & $\sqrt{ }$ & $\sqrt{ }$ & Sustainable competitive advantage \\
\hline Intangible & Reputation & $\sqrt{ }$ & $\sqrt{ }$ & $\sqrt{ }$ & $\sqrt{ }$ & Sustainable competitive advantage \\
\hline Intangible & Product quality & $\sqrt{ }$ & $\sqrt{ }$ & $x$ & & Temporary competitive advantage \\
\hline Intangible & Compliance & $\sqrt{ }$ & $\sqrt{ }$ & $x$ & & Temporary competitive advantage \\
\hline Intangible & Intellectuality & $\sqrt{ }$ & $x$ & & & Competitive parity \\
\hline Capability & Continuous improvement & $\sqrt{ }$ & $\sqrt{ }$ & $\sqrt{ }$ & $\sqrt{ }$ & Sustainable competitive advantage \\
\hline Capability & Continuous learning & $\sqrt{ }$ & $\sqrt{ }$ & $\sqrt{ }$ & $\sqrt{ }$ & Sustainable competitive advantage \\
\hline Capability & Change management & $\sqrt{ }$ & $\sqrt{ }$ & $\sqrt{ }$ & $\sqrt{ }$ & Sustainable competitive advantage \\
\hline Capability & Risk management & $\sqrt{ }$ & $x$ & & & Competitive parity \\
\hline Capability & Supply chain management & $\sqrt{ }$ & $\sqrt{ }$ & $\sqrt{ }$ & $\sqrt{ }$ & Sustainable competitive advantage \\
\hline Capability & Human resources development capability & $\sqrt{ }$ & $\sqrt{ }$ & $\sqrt{ }$ & $\sqrt{ }$ & Sustainable competitive advantage \\
\hline Capability & Customer service & $\sqrt{ }$ & $\sqrt{ }$ & $\sqrt{ }$ & $\sqrt{ }$ & Sustainable competitive advantage \\
\hline Capability & Selling skill & $\sqrt{ }$ & $\sqrt{ }$ & $\sqrt{ }$ & $x$ & Unused competitive advantage \\
\hline Capability & General managerial capability & $\sqrt{ }$ & $\sqrt{ }$ & $\sqrt{ }$ & $\sqrt{ }$ & Sustainable competitive advantage \\
\hline Capability & Marketing skill & $\sqrt{ }$ & $\sqrt{ }$ & $x$ & & Temporary competitive advantage \\
\hline
\end{tabular}

The core competencies that derive from the intangible resources most mentioned by respondents are about reputation. This core competency was mentioned by respondent 4 , respondent 5 , respondent 6 , respondent 9 , and respondent 10 . They mentioned that Kalbe gave the reputation in the field of the medical device, which is a parent company that does have a track record of more than 50 years in the healthcare sector in Indonesia. Its reputation has been built from time to time, which has supported EMP's reputation. There are also other core competencies mentioned by respondent 10, namely customer relationship, the commitment that is management commitment or Kalbe's board of directors for all of its subsidiaries and coordination and collaboration are synergies between Kalbe subsidiaries. 
In addition to core competencies sourced from tangible and intangible resources, there are also EMP core competencies that come from capabilities. The most mentioned capability is customer services mentioned by respondent 10 , respondent 13 , and respondent 5 . These customer services are after-sales service mentioned by respondent 10 , handling customer complaints within 24 hours mentioned by respondent 13 and customer service before and after-sales mentioned by respondent 5 . In addition, there are also general managerial skills mentioned by respondent 10 , continuous learning mentioned by respondent 3 , continuous improvement mentioned by respondent 3 , change management mentioned by respondent 4 , supply chain management mentioned by respondent 14 and the human resource development capabilities mentioned in the form of ongoing training and development mentioned by respondent 13 .

The conclusion of the management in-depth interview was delivered to the directors. It provided an overview before the in-depth interview process was carried out and also as a form of confirmation. The results of the directors' in-depth interviews show that the core competencies sourced from tangible resources include distribution facilities with Kalbe support in almost all regions in Indonesia so that they have extensive coverage.

Financial resources are financial strength with the support of the parent company, whereas business process systems are internal systems, business processes that have been built and structured. Core competencies originating from intangible resources are product quality, which means prioritizing quality, which is more important than other aspects. The reputation intended is a reputation in the field of medical devices with support and originating from the parent company. The core competencies in the form of customer relationship mentioned are strictly intertwined relationships that originate from the quality and intensity of the relationship. Furthermore, coordination and collaboration, which become core competencies mean coordination, collaboration, and internal alignment and fellow Kalbe group companies. Company value is the value adopted and derived from the parent company Kalbe while the corporate network is a broad corporate network with all existing stakeholders such as business partners, distributors, governments, customers, and professional organizations.

Table 5 - VRIO analysis from director perceptions

\begin{tabular}{|c|c|c|c|c|c|c|}
\hline Category & Resources or Capabilities & V? & $\mathrm{R} ?$ & I? & $\mathrm{O} ?$ & Competitive implication \\
\hline Tangible & Distribution facilities & $\sqrt{ }$ & $\sqrt{ }$ & $\sqrt{ }$ & $\sqrt{ }$ & Sustainable competitive advantage \\
\hline Tangible & Number of sales forces & $\sqrt{ }$ & $x$ & & & Competitive parity \\
\hline Tangible & Business process system & $\sqrt{ }$ & $\sqrt{ }$ & $\sqrt{ }$ & $\sqrt{ }$ & Sustainable competitive advantage \\
\hline Tangible & Financial resources & $\sqrt{ }$ & $\sqrt{ }$ & $\sqrt{ }$ & $\sqrt{ }$ & Sustainable competitive advantage \\
\hline Intangible & Reputation & $\sqrt{ }$ & $\sqrt{ }$ & $\sqrt{ }$ & $\sqrt{ }$ & Sustainable competitive advantage \\
\hline Intangible & Product quality & $\sqrt{ }$ & $\sqrt{ }$ & $\sqrt{ }$ & $\sqrt{ }$ & Sustainable competitive advantage \\
\hline Intangible & Compliance & $\sqrt{ }$ & $x$ & & & Competitive parity \\
\hline Intangible & Customer relationship & $\sqrt{ }$ & $\sqrt{ }$ & $\sqrt{ }$ & $\sqrt{ }$ & Sustainable competitive advantage \\
\hline Intangible & Coordination and collaboration & $\sqrt{ }$ & $\sqrt{ }$ & $\sqrt{ }$ & $\sqrt{ }$ & Sustainable competitive advantage \\
\hline Intangible & Corporate value & $\sqrt{ }$ & $\sqrt{ }$ & $\sqrt{ }$ & $\sqrt{ }$ & Sustainable competitive advantage \\
\hline Intangible & Company network & $\sqrt{ }$ & $\sqrt{ }$ & $\sqrt{ }$ & $\sqrt{ }$ & Sustainable competitive advantage \\
\hline Capability & General managerial capability & $\sqrt{ }$ & $\sqrt{ }$ & $\sqrt{ }$ & $\sqrt{ }$ & Sustainable competitive advantage \\
\hline Capability & Customer service & $\sqrt{ }$ & $\sqrt{ }$ & $\sqrt{ }$ & $\sqrt{ }$ & Sustainable competitive advantage \\
\hline Capability & Implementation skill & $\sqrt{ }$ & $\sqrt{ }$ & $\sqrt{ }$ & $\sqrt{ }$ & Sustainable competitive advantage \\
\hline Capability & Change management & $\sqrt{ }$ & $\sqrt{ }$ & $x$ & & Competitive parity \\
\hline Capability & Financial management & $\sqrt{ }$ & $x$ & & & Competitive parity \\
\hline
\end{tabular}

In addition to core competencies sourced from tangible and intangible resources, there are also core competencies that derive from capabilities. The first is a general managerial capability, which means team managerial capability as a whole starting from the Board of Directors at Kalbe to managerial levels at the subsidiary level. Overall, they form excellent managerial capabilities that are not easily replicated. Also, it is reinforced by the core competency of the implementation capability, which means the capability to execute overall business processes. The last is customer service, which means providing the best service to customers, which is indeed a culture handed down by Kalbe to all of its subsidiaries. 
Comparing the core competencies mentioned by management and directors, several core competencies have strong correlations. Two different groups of respondents mentioned those core competencies, which mean that management and directors have a common perception of these core competencies. It can be said as EMP core competence. The core competencies that fit these criteria are distribution facilities, financial resources, reputation, customer relationship, coordination and collaboration, customer service, and general managerial capabilities. The seven core competencies are also confirmed when viewed from the business partner's perception of the resources and capabilities possessed by EMP, which is the business partner consideration in choosing them to become business partners who market their products. These core competencies are the company's strength and unique competencies compared to its competitors or in other words, bring EMP to compete competitively and have a sustainable competitive advantage in the medical device market.

Table 6 - Comparison of core competencies of management and director perceptions, and resources and capabilities of business partners' perceptions

\begin{tabular}{|c|c|c|}
\hline $\begin{array}{l}\text { Resources and capabilities of } \\
\text { business partners perceptions }\end{array}$ & $\begin{array}{l}\text { Core competencies of management } \\
\text { perceptions }\end{array}$ & $\begin{array}{l}\text { Core competencies of director } \\
\text { perceptions }\end{array}$ \\
\hline \multicolumn{3}{|c|}{ Tangible resources } \\
\hline $\begin{array}{l}\text { Distribution coverage throughout } \\
\text { Indonesia } \\
\text { Number of sales forces } \\
\text { Financial resources } \\
\text { Business process system }\end{array}$ & $\begin{array}{l}\text { Distribution facilities } \\
\text { Number of sales forces } \\
\text { Financial resources } \\
\text { Product portfolio }\end{array}$ & $\begin{array}{l}\text { Distribution facilities } \\
\text { Financial resources } \\
\text { Business process system }\end{array}$ \\
\hline \multicolumn{3}{|c|}{ Intangible resources } \\
\hline $\begin{array}{l}\text { Professionalism } \\
\text { Reputation derived from parent } \\
\text { company } \\
\text { Customer relationship } \\
\text { Compliance } \\
\text { Consistency }\end{array}$ & $\begin{array}{l}\text { Reputation } \\
\text { Customer relationship } \\
\text { Commitment } \\
\text { Coordination and collaboration }\end{array}$ & $\begin{array}{l}\text { Product quality } \\
\text { Reputation } \\
\text { Customer relationship } \\
\text { Coordination and collaboration } \\
\text { Company value } \\
\text { Corporate Network }\end{array}$ \\
\hline \multicolumn{3}{|c|}{ Capabilities } \\
\hline $\begin{array}{l}\text { Continuous improvement } \\
\text { Continuous learning } \\
\text { General managerial capability } \\
\text { Marketing management } \\
\text { Change management } \\
\text { Information system management }\end{array}$ & $\begin{array}{l}\text { Customer service } \\
\text { General managerial capability } \\
\text { Continuous improvement } \\
\text { Continuous learning } \\
\text { Change management } \\
\text { Supply change management } \\
\text { Human resources development } \\
\text { capability }\end{array}$ & $\begin{array}{l}\text { General managerial capability } \\
\text { Implementation capability } \\
\text { Customer service }\end{array}$ \\
\hline
\end{tabular}

Different types of business can have different core competencies. The value of a company's resources is determined by the specific market context in which it operates (Barney 2001; Priem and Butler 2001). If we compare it with the type of business that has similar types of customers, for example, is the pharmaceutical industry. Technology, marketing and regulation are very valuable competencies in the context of the pharmaceutical industry (Cool and Schendel 1988; Henderson and Cockburn, 1994, 1996; Hill and Hansen, 1991; Thomas, 1990). In the pharmaceutical industry, the spread of strong marketing capabilities has an impact on the success of new drugs. Pharmaceutical companies rely on highly trained salespeople representing their products to doctors and health institutions. Sales people are intensively trained to have knowledge about the drugs being promoted to their various customers. Strong marketing competence can make a big difference in market share for drugs of the same type. It is similar to the medical device market, which does require the same approach to marketing in the pharmaceutical industry.

Specifically in terms of marketing, conceptually, marketing competence refers to the company's ability to develop and maintain customer relationships, the ability to use marketing intelligence against external factors that might affect current and future customer needs (Mooreman and Slotegraaf 1999). EMP as it is known is a marketing company. In this study, marketing and sales skills or capabilities are not core competencies of EMP. It has other advantages which are the seven core competencies that support its main activities, namely 
marketing where distribution facilities, reputation, customer relations and customer service can be perceived as having a direct relationship towards marketing competence.

Based on the opinion of Hamel and Prahalad (1990) that companies are like a tree that grows from its roots. The core competencies maintain the core product and give rise to a business unit, whose fruit is the final product. Thus, the EMP core competency tree can be formed to describe the structure and flow of competencies that shape its competitive advantage. Figure 2 presents the core competency tree.

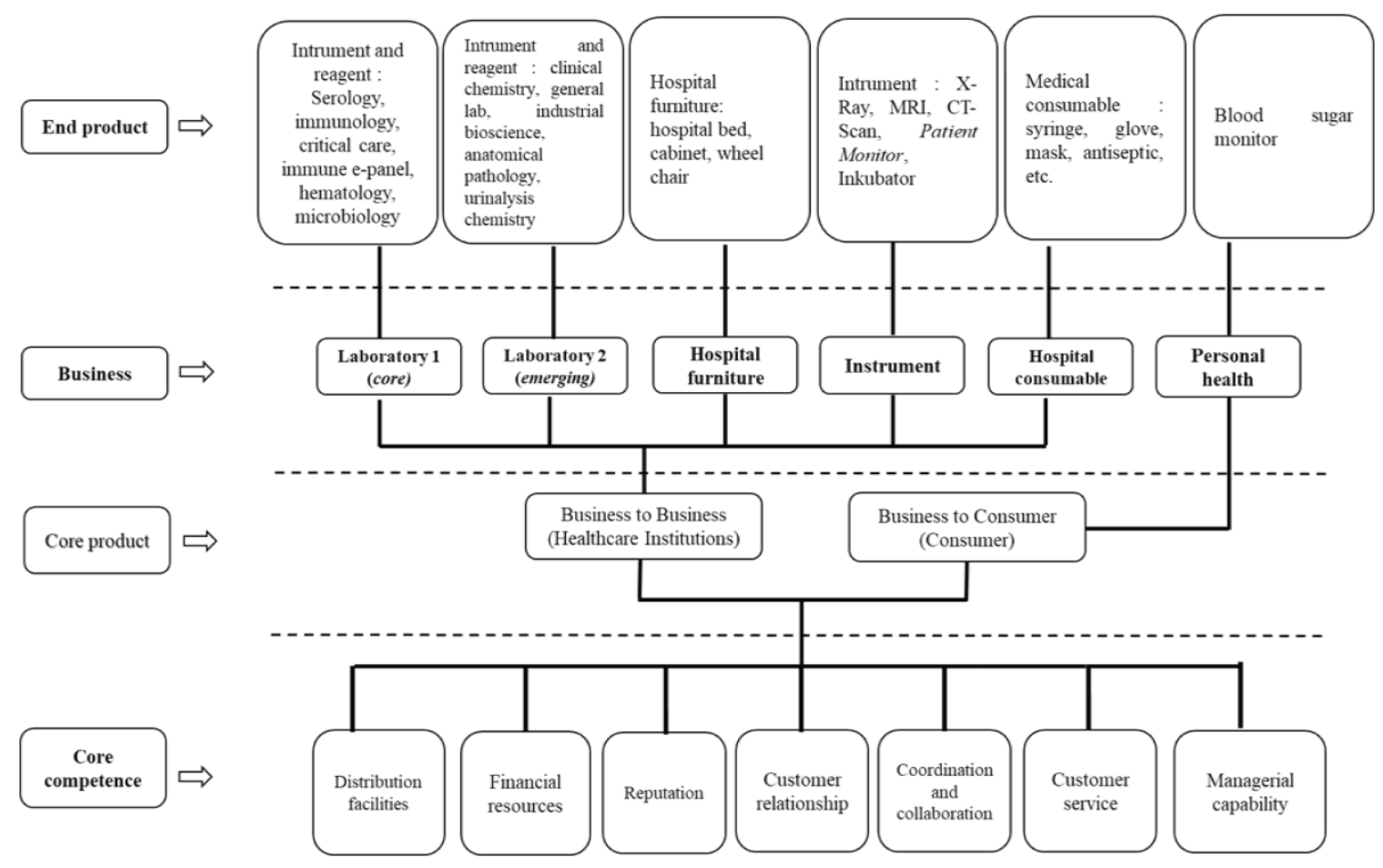

Figure 2 - The roots of competitiveness of EMP

Figure 2 explains that EMP integrates the core competencies of distribution facilities, financial resources, reputation, customer relationship, coordination and collaboration, customer service and managerial capabilities. These are its strengths as a strategy to run two types of core products namely products for business to business (B2B) healthcare institutions such as hospitals, clinics, laboratories, healthcare centers and products for business to consumer (B2C) with direct consumers. These two types of core products bring up six types of businesses, namely core laboratories, emerging laboratories, hospital furniture, hospital consumables, and instruments on B2B and personal health on B2C with each having different characteristics of product lines.

\section{CONCLUSION}

The core competencies come from tangible resources, intangible resources, and capabilities owned by the company. However, only resources and capabilities that have specific characteristics that can be the core competencies of a company. Resources and capabilities that meet four criteria which are valuable, rare (rare/unique), costly to imitate (expensive to imitate), and organization (organized) referred to as core competencies. The core competencies of EMP that fit these criteria are distribution facilities, financial resources, reputation, customer relationship, coordination and collaboration, customer service, and general managerial capabilities. These core competencies are the company's strength and unique competencies compared to its competitors or in other words, bring EMP to compete competitively and have a sustainable competitive advantage in the medical device market. 


\section{REFERENCES}

1. Barney JB. 1991. Firm resources and sustained competitive advantage. Journal of Management. 17(1): $99-120$.

2. Barney JB. 2001. Is the resource-based "view" a useful perspective for strategic management research? Yes. Academy of Management Review. 26(1): 41-56.

3. Barney JB and William SH. 2015. Strategic Management and Competitive Advantage: Concepts and Cases. Fifth Edition. USA: Pearson Education Inc.

4. Cool K and Schendel D. 1988. Performance differences among strategic group members. Strategic Management Journal. 9(3): 207-223.

5. David FR. 2011. Strategic Management Concepts and Cases. New Jersey (USA): Pearson Education Inc.

6. Geertz C. 1973. The Interpretation of Cultures: Selected Essays. New York (USA): Basic Books.

7. Hamel G and Prahalad CK. 1990. The core competence of the corporation. Harvard Business Review. 71-91.

8. Henderson R and Cockburn I. 1994. Measuring competence? Exploring firm effects in pharmaceutical research. Strategic Management Journal. 15: 63-84.

9. Henderson R and Cockburn I. 1996. Scale, scope and spillovers: the determinants of research productivity on drug discovery. Rand Journal of Economics. 27(1): 32-69.

10. Hitt MA, Ireland RD, Hoskisson RE. 2017. Strategic Management Competitiveness \& Globalization Concepts and Cases. 12th ed. Boston (USA): Cengage Learning.

11. Hill C and Hansen G. 1991. A longitudinal study of the cause and consequences of changes in diversification in the U.S. pharmaceutical industry 1977-1986. Strategic Management Journal. 12: 187-199.

12. MacDonald $\mathrm{BH}$. 2007. When numbers alone are not enough: applications of qualitative methodologies. Feliciter. 53(1): 26-29.

13. Mooreman C and Slotegraaf R. 1999. The contingency value of complementary capabilities in product development. Journal of Marketing Research. 36: 239-257.

14. Peteraf MA and Barney JB. 2003. Unraveling the resource-based triangle. Managerial and Decision Economics. 24: 309-323.

15. Pharmaboardroom. 2018. Indonesia Facts and Figures Snapshot [internet]. [accessed 3 January 2018]. Available from https://pharmaboardroom.com/facts/indonesia-factsfigures-snapshot/.

16. Thomas LG. 1990. Regulation and firm size: FDA impacts on innovation. Rand Journal of Economics. 21(4): 497-517.

17. Porter RM. 1985. Competitive Advantage Creating and Sustaining Superior Performance. New York (USA): The Free Press.

18. Priem R and Butler J. 2001. Is the resource-based view a useful perspective for strategic management research? Academy of Management Review. 26(1): 22-40.

19. Putera AD. 2018. 92 Persen Alat Kesehatan di Indonesia dari Impor, Ini Fakta Lainnya [internet]. Available from https://ekonomi.kompas.com/read/2018/10/16/170326526/92persen-alat-kesehatan-di-indonesia-dari-impor-ini-fakta-lainnya.

20. Schreyogg $G$ and Kliesch-Eberl M. 2007. How dynamic can organizational capabilities be? Towards a dual-process model of capability dynamization. Strategic Management Journal. 913-933.

21. Simbolon F. 2018. Industri alat kesehatan keluhkan harga jual yang terlalu rendah [internet]. Available from https://industri.kontan.co.id/news/industri-alat-kesehatankeluhkan-harga jual-yang-terlalu-rendah.

22. Sumarwan U, Hartoyo, Fahmi I. 2018. Metode Riset Bisnis dan Konsumen. Edisi revisi. Bogor (ID): PT Penerbit IPB Press.

23. Wernerfelt B. 1984. A resource-based view of the firm. Strategic Management Journal. 5: 171-180.

24. Wheelen TL and Hunger JD. 2012. Strategic Management and Business Policy toward Global Sustainability. 13th ed. New Jersey (USA): Pearson Education Inc. 